\title{
Why a U.S.-China Trade Deal will not Ensure an Effective Global Trade Governance
}

\author{
Habib Kazzi \\ Professor of International Trade Law (Lebanese University), \\ Lawyer at the Paris Bar (France), \\ Senior Consultant
}

Doi:10.19044/esj.2019.v15n16p191 URL:http://dx.doi.org/10.19044/esj.2019.v15n16p191

\begin{abstract}
This contribution makes the case for the building of a constructive partnership between China and global players, including the United States, the only way to tackle China's trade policy challenges and ensure effective global trade governance. After months-long negotiations, the United States and China may put the finishing touches on a trade deal to end their trade war. Despite advances secured by the U.S., it should be admitted that once again, when it comes to negotiations with China, it is a matter of much ado about nothing. China will remain a unique and pressing challenge for the WTO and its trading partners. It appears that China's trade distortions are the outcome of a singular China's political and legal system promoting a socialist market economy with a state-led and mercantilist trade regime. The trade deal, through its enforcement offices, will not be able to prevent the U.S. from imposing unilateral sanctions against China, nor will it be able to minimise strategic competition between the two States. In this context, pursuing unilateral measures and sanctions to obtain structural reforms protecting U.S. workers, farmers and businesses is largely a futile exercise. Rather, modernizing the China's economic and legal architecture than reforming it should be the cornerstone of a realistic, multifaceted and long-term approach based on a constructive diplomacy, including the creation of new institutions such as a bilateral investment treaty with China and the accession to the TransPacific Partnership, as well as a joint working group on WTO reform with like-minded States capable of exerting upward pressure on China so as to revitalize WTO rules and functions.
\end{abstract}

Keywords: U.S.-China Trade Deal, Global Trade Governance, Trade Barriers, China's Foreign Investment Law, WTO Reform. 


\section{INTRODUCTION}

The Trump administration's National Security Strategy delivered in December 18, 2017 marked a significant turning point in the U.S. foreign policy. Characterizing the world as a competitive arena rather than a "community of nations" or an "international community", this statement identifies two primary rivals, Russia and China, named as "revisionist powers" on the grounds that these two States "(...) challenge American power, influence, and interests, attempting to erode American security and prosperity. They are determined to make economies less free and less fair".

As of this date, only one year after coming into office, as part of “America first foreign policy", Trump's administration steadily and constantly reaffirms that the United States "will no longer tolerate economic aggression or unfair trading practices".

With China, the U.S. government's position is based on the deficit in the trade balance which is expected to hit a record $\$ 400$ billion and the analysis of China's record as a WTO member since 2001. WTO membership comes with expectations that an acceding member not only will strictly adhere to WTO rules, but also will support and pursue open, market-oriented policies. The pursuit of market-oriented policies means not only strictly adhering to the agreed rules but also observing in good faith the fundamental principles that run throughout the many WTO agreements, which include non-discrimination, openness, reciprocity, fairness and transparency. Clearly, China has not made sufficient progress in transitioning toward a market economy. This country continues to embrace a state-led, non-market and mercantilist approach to the economy and trade (USTR, Report March 2018).

China's strategy results in vast and sophisticated policies that often evade WTO disciplines and fundamental principles, causing serious prejudice to markets, industries and workers in the United States and other WTO Members, even as China reaps enormous benefits from its WTO membership. China's trade policies and practices in various specific areas concretely cause particular concerns for U.S. stakeholders. The key concerns in each of these areas relate primarily to China's industrial policies, including forced technology transfer, State-owned Enterprises (SOEs), investment restrictions and subsidies to its domestic industries. Other key concerns include non-tariff trade barriers, protection of intellectual property rights, cyber intrusions and technology theft, services market access and agricultural trade, among other areas.

Faced with almost two decades of China's intransigence, the United States has adopted a more aggressive multifaceted strategy. On the grounds of national security under Section 232 of the Trade Expansion Act of 1962 and under Section 301 of the Trade Act of 1974, the United States imposed duties on $\$ 250$ billion dollars' worth of Chinese imports, and is using several 
available tools to respond to the challenges presented by China, including domestic trade remedies, bilateral negotiations, WTO litigation and strategic engagement with like-minded trading partners.

China accuses the U.S. of launching the largest trade war in economic history with the objective of embracing broader structural changes, which are seen by some as a way to contain its rise. In reprisal for U.S. measures, China has hit back with tariffs on about $\$ 110$ billion dollars of U.S. goods, including many agricultural products, in excess of China's bound rates. In addition, the China's General Administration of Customs assesses duties on U.S. products based on higher "reference prices," rather than the declared value, effectively resulting in even higher tariffs. Tariff escalations between the U.S. and China were, ultimately, of particular concern given the scale of trade items covered by their additional tariffs given that the U.S. has imposed tariffs on half of its imports from China, while China has imposed retaliatory tariffs on two-thirds of its imports from the U.S.

The one-year trade war between the world's two largest economies has raised costs, roiled financial markets, shrunk U.S. farm exports and disrupted manufacturing supply chains (REUTERS, March 19, 2019). As part of an effort to defuse the crisis, plans for trade talks were made between Trump and Xi Jinping during the Group of 20 summit in Buenos Aires in December 2018. After tough negotiations, warring parties are on the verge of reaching a comprehensive agreement exceeding 150 pages.

The main legacy of this agreement is the restoration of a bilateral dialogue. While all bilateral trade mechanisms between these countries have all been cut off since Trump took office, this agreement may constitute an appropriate institutional framework to ease trade relations and bridge the gap between the viewpoints about multilateral and bilateral issues. At the same time, there is no reason to turn over-optimistic. Experts point out that an easing of tensions between the warring parties is not going to stop the slowdown already seen in the global economy (NEE LEE, 2019). Worse still, there would probably be a lack of progress in addressing concretely several critical and thorny issues between the U.S. and China, including effective enforcement of intellectual property rights, subsidies for State-owned enterprises and Chinese technological champions, investment restrictions, the control of local governments' policies, and the use by the Chinese government of its judicial system and legislations with the goal to discipline the domestic market and achieve industrial policy objectives, among others.

Getting China to agree to stop doing this will be close to impossible. That means global uncertainties brought about by tensions between the U.S. and China may drag on longer. All these current issues remind players of global trade of the need for an urgent establishment of a sustainable and 
realistic multifaceted "win-win" strategic dialogue that benefits both sides and, ultimately, optimizes the multilateral trading system.

To better understand what is at stake, the remaining article is organized as follows. Section I stresses political and legal grounds of China's economic model. Section II focuses on the new China's foreign investment legal framework. Section III examines main features and issues of the current U.S. multi-faceted strategy with China. Section IV proposes some recommendations through the building of a "constructive partnership" between China and its major trading partners, the only way to ensure a more realistic and sustainable global trade governance. Finally, Section V concludes.

\section{SECTION I: China's Socialist Market Economy and Legal System}

During trade bilateral negotiations, U.S. negotiators had a lot of ambition that the State apparatus was finally going to retreat and the market would thrive. But today, the outcomes of these negotiations symbolize the gap between U.S. stakeholders' expectations and Chinese commitments and performance. They also show how Trump's hopes of winning genuine structural changes in China's economic model are colliding with the entire thrust of Xi's rule, which has been all about bolstering Beijing's role in the economy while preserving Communist Party control. State involvement in the economy indeed remains considerable. Almost two decades after China joined the WTO, the Chinese state maintains a tight grip on virtually all economic activity. To fully appreciate the challenges faced by foreign investors and exporters, and the intransigence of Chinese authorities to adopt structural changes, it is vital to achieve a thorough examination of economic, political and legal grounds of current China's proactive and state-driven industrial and economic policies such as "Made in China 2025".

\section{1) Economic Environment}

China's economic model is undergoing profound transformation (CANUTO, 2019). While the Chinese economy continued to be a major driver of global economic growth, China's growth has been in a downslide trend since 2011. It has become hard for the Chinese government to push through credible reforms as the economy slows. Real GDP growth has been moderating as the economy adjusts to the "new normal", which implies more stable, albeit lower, growth rates of around $7 \%$ per year in the foreseeable future. On the other hand, China's economic structure has gradually rebalanced growth from investment to consumption, from external to internal demand, and from manufacturing to services. In this context, China is not willing to pay any kind of cost for structural changes in the coming years. The 
goal is to ensure a balance between the ambition to steer the economy toward a high-tech and dominant position, and the need to avoid economic turbulence.

\section{2) Legal and Political Regime}

An in-depth analysis of China's Constitution, relevant directives and pronouncements by China's leadership, legislative and regulatory measures issued by the Chinese government, China's industrial plans and the actions of the Chinese government and the Chinese Communist Party leaves no doubt that the Chinese state still maintains control over economic decision-making in that country.

Consultations and dialogue on high policy level for several years indicate that China has no plans to significantly change its basic approach to the economy. As China explained in the report that it circulated in connection with its July 2018 trade policy review at the WTO, "[w] hile socialism with Chinese characteristics has entered a new era, the basic dimension of the Chinese context - that China is still and will long remain in the primary stage of socialism - has not changed." China added that it is committed to a "socialist market economy" and to improving "the relationship between the government and the market." In China's view, an improved relationship seems to indicate that the State plays its role better in managing the economy, not that the State ceases to intervene and allows market forces to determine outcomes.

The government and the Communist Party have constitutional mandates to develop a "socialist legal system" and a "socialist market economy with Chinese characteristics."

The preamble of the Constitution of the People's Republic of China stresses that "After the founding of the People's Republic, the transition of Chinese society from a new democratic to a socialist society was effected step by step (...).China will stay in the primary stage of socialism for a long period of time. The basic task of the nation is to concentrate its efforts on socialist modernization along the road of Chinese-style socialism. Under the guidance of Marxism-Leninism, Mao Zedong Thought, Deng Xiaoping Theory and the important thought of 'Three Represents', the Chinese people of all nationalities will continue to adhere to the people's democratic dictatorship, follow the socialist road, persist in reform and opening-up, steadily improve socialist institutions, develop a socialist market economy".

In line with this vision, article 5 of the Constitution provides for a socialist legal system and rule of law by stressing that "The People's Republic of China practices ruling the country in accordance with the law and building a socialist country of law. The state upholds the uniformity and dignity of the socialist legal system". 
Going still further, Article 6 of the Constitution provides that, "[i]n the primary stage of socialism, the state upholds the basic economic system in which public ownership is dominant and diverse forms of ownership develop side by side (....)". Article 7 also provides that "[t]he state-owned economy, that is, the socialist economy with ownership by the whole people, is the leading force in the national economy. The state ensures the consolidation and development of the state-owned economy." Under article 11 of the Constitution, "The State protects the lawful rights and interests of the nonpublic sectors of the economy such as the individual and private sectors of the economy. The State encourages, supports and guides the development of the non-public sectors of the economy and, in accordance with law, exercises supervision and control over the non-public sectors of the economy".

Similarly, the Constitution of the Chinese Communist Party (CCP) provides: "The Communist Party of China leads the people in developing the socialist market economy. It unwaveringly consolidates and develops the public sector of the economy and unswervingly encourages, supports and guides the development of the non-public sector."

The prevalence of the State apparatus and its failure to embrace the pursuit of open, market-oriented policies, was recently underlined by the WTO Secretariat in its report prepared for the seventh trade policy review of China in 2018 highlighting that "The Government has been trying to address these issues by focusing on the quality and sustainability rather than the quantity of growth. Under the $13^{\text {th }}$ Five-Year Plan (2016-2020), the authorities intend to continue the process of structural economic reform, which includes the promotion of private sector participation in the economy, as well as the reform of SOEs, while keeping the preponderance of public ownership."

To fulfill these mandates, the Government and the Party direct and channel economic actors to meet the State's planning targets. They permit market forces to operate only to the extent that they accord with the objectives of national economic and industrial policies. When there is conflict between market outcomes and State objectives, the Government and the Party intervene to ensure that the State's objectives prevail.

This diagnosis has been confirmed with the recent passing of the China's Foreign Investment Law. While Chinese analysts stress that this law reflects China's desire to improve its economy and legal system, it is unlikely that this new legal instrument will level the playing field for foreign investors. Foreign business community and legal consultants still express skepticism about how far the law would protect foreign firms' interests, given the China's political system and the lack of rule of law in this country. The risk is high that the Investment law was nothing but smoke and mirrors used by Chinese government and CCP in response to the trade war with the United States and to avoid an overhaul of the current political regime and foreign policy. Indeed, 
the larger problems are deeply rooted in China's political system. The reality is that, so long as the CCP remains focused on asserting its authority across all aspects of Chinese society, foreign companies will need to operate in such a way that their business is not perceived as undermining CCP rule or social stability. Not surprisingly, and like other Chinese legislations and directives, article 1 reiterates that this law meets economic objectives made to serve a model of society and a national development policy. It provides that "This Law is formulated on the basis of the Constitution to further expand the scope of opening-up, to actively promote foreign investment, to protect the lawful rights and interests offoreign investment, to make new grounds in opening up on all fronts, and to promote the healthy development of the socialist market economy".

Moreover, in light of China's approach to foreign policy in recent years, it remains unlikely that foreign investors will be treated by the Chinese government as anything other than an extension of the interests of their own country of origin. As long as Chinese leadership sees its own industry giants and businesspeople as manifestations of China's own national interests, it will treat foreign entities and citizens in the same way. If the rule of law is then abrogated to exact retribution for the actions of foreign governments on an $\mathrm{ad}$ hoc basis, legislation such as the pending Foreign Investment Law will be rendered ineffective, if not meaningless, over the long term.

In this context, how do Chinese authorities grasp these arguments?

From China's view, recurrent accusations from U.S. stakeholders about its WTO compliance lack factual and legal basis (Reuters, February 5, 2018). Too often, a considerable part of these accusations against China exceeds its commitments to the WTO. Rather, USTR's reports on this topic would be based on U.S. domestic law rather than WTO agreements and multilateral rules. The Chinese government also notes that this country plays a constructive role at such a decisive moment as this for the WTO. Indeed, China clearly opposes unilateralism and protectionism and, as a result, firmly acknowledges the crucial role played by the WTO in preserving fair, predictable, and transparent trade rules. Its support to the multilateral trading system is recently reflected in the acceptance to participate in the reform of the WTO, in particular the dispute settlement system, to adapt it to a changing global economy. While, the volume of Chinese trade covered by FTAs remains small, China also continues to grant unilateral trade preferences to LDCs. As of December 2017, duty-free treatment on $97 \%$ of tariff lines was granted to LDCs (WTO Secretariat, 2018).

\section{SECTION II: China's Foreign Investment Policy and Laws}

Foreign investment has become a significant driving force in the rapid development of the Chinese economy. Until October 2018, almost 950,000 
foreign-invested companies with more than U.S. \$2.1 trillion foreign capital were registered to operate in China. As the second largest economy in the world, China received record foreign direct investment (FDI) in 2017, ranked just behind the U.S. (HEALEY and WANG, 2019).

In accordance with WTO commitments, the Catalogue of Industries for the Guidance of Foreign Investment (Investment Catalogue), as revised in 2017, was long considered as the main instrument used to guide FDI in China. Under the Catalogue, foreign investment projects are classified in the encouraged category and in a "Negative List", which contains a list of industries where FDI is restricted or prohibited. Foreign-invested projects (FIPs) in China are subject to approval or to record-filing. Projects subject to approval are listed in a specific catalogue, while most projects not included in it were subject to record-filing. Approval requires the examination of the investment project, and a number of conditions must be met. Projects in the encouraged category are eligible for preferential treatment, for example, customs duty exemptions for the importation of equipment. The 2017 revision of the Catalogue encourages FDI in, inter alia, advanced manufacturing, high technology, the energy saving and environmental protection industry, and the modern services industry (WTO Secretariat Report, 2018).

Under the Agreement on Trade-Related Investment Measures (TRIMS Agreement), China committed to eliminate some measures such as those that require or provide benefits for the incorporation of local inputs (known as local content requirements) in the manufacturing process, or measures that restrict a firm's imports to an amount related to its exports or related to the amount of foreign exchange a firm earns (known as trade balancing requirements). In its WTO accession agreement, China also agreed to eliminate export performance, local content and foreign exchange balancing requirements from its laws, regulations and other measures, and not to enforce the terms of any contracts imposing these requirements. In addition, China agreed that it would no longer condition importation or investment approvals on these requirements or on requirements such as technology transfer and offsets (WTO, China Report, 2018)..

However, China still utilizes various investment restrictions designed to protect domestic manufacturers and services suppliers from foreign competitors and to encourage technology transfer. This country still commits acts of discrimination against foreign investors that do not permit level playing field, through an administrative filing-record or approval system providing a case-by-case review of any foreign investment. While no technology transfer requirements are imposed on foreign investment projects according to the Chinese authorities, FDI involving investments in Chinese domestic enterprises may be subject to national security reviews if the FDI is related to defense, or is deemed to have an influence on national security. In this respect, 
foreign investors regularly express a deep concern about the use of a broad definition of "national security," which includes factors such as economic, cultural and financial security, by China's regulatory authorities when implementing the negative list. The United States is also concerned about many other aspects of the national security review, including its application to greenfield investments and the invitation for Chinese competitors to nominate transactions for review. In addition, China's investment restrictions are often accompanied by other problematic industrial policies, such as the development of China-specific standards and the increased use of subsidies. At the same time, foreign investors in China also continue to voice concerns about lack of transparency in China's foreign investment policy, inconsistent enforcement of laws and regulations, weak IPR protection, corruption and a legal system that is unreliable and fails to enforce contracts and judgments (USTR Report, 2019).

To allay foreign investor' concerns, and as a response to U.S.-China Talks, the first China's Foreign Investment Law (Investment Law) has been adopted by the 2nd Session of the 13th National People's Congress on March 15, 2019 and shall take effect on January 1, 2020. This instrument streamlines the current foreign investment law regime by replacing existing regulations for joint ventures and wholly foreign-owned enterprises with a five-year transition period, and eases foreign concerns about China's investment environment. Wang Chen, vice chairman of parliament's standing committee, pointed out that full session of the legislature that the law "[i]ncludes many stipulations that ensure domestic and foreign enterprises are subject to a unified set of rules and compete on a level playing field". It will "create a stable, transparent and predictable market environment featuring fair competition", he added. At the same time, this legal instrument should also ultimately work to China's interests. Liberalizing and facilitating foreign investment should increase confidence in China's investment environment and attract more high-quality investment, especially in areas of high-tech and innovation which will contribute to China's overarching policy objectives set out in the 13th Five Year Plan and "Made in China 2025".

Literally, the Investment Law aims at offering foreigners equal treatment, greater market access and better legal protection. For this purpose, it includes rules on investment promotion (Chapter 2), protection (Chapter 3), and management (Chapter 4). Amongst main changes, it guarantees equal treatment for domestic and foreign business, and bans forced technology transfer and illegal government "interference" in foreign business practices. More importantly, it fully implements pre-establishment national treatment plus a "Negative List" for foreign investments, expanding market access for foreign investors whilst increasing the predictability and transparency of foreign investment administration. 
While the Investment Law makes a positive step towards improving the legal system in China with "promising results" (HEALEY and WANG, 2019), some analysts stress that this legislation clearly "fails to address US Concerns" and, more generally, "raises concerns" for foreign investors as a whole (LOWE, 2019).

Progresses achieved do not effectively serve as an answer to longstanding U.S. demands on these issues. Analysts note that the way this law was "rushed through", the problematic deadline set for the change of original corporate organizational forms, and the vague wording of many of its 42 clauses are casting some serious doubts on authorities' ability to enforce the legislation after it is passed (LOWE, 2019).

While the Investment Law will have major ramifications for all foreign companies in China for the foreseeable future, it was rushed through a significantly shortened deliberative process. The legislation was approved just three months after a first draft was debated, including a three-day legislative session and a short period for solicitation of public comments. Few and scattered negotiations and one-way communication with foreign companies and trading partners have marked drafting and voting processes. This instrument has, in fact, served as an olive branch to ease trade tensions with Washington by demonstrating China's commitment to using reform and innovation to ensure its foreign investment legal system develops and improves. It is striking to note that the content and scope of this law have not been discussed during trade talks, thus not enabling U.S. negotiators to impose concrete amendments and guarantees (QINGJIANG and WEIHUAN, 2019).

The draft's expedited review and the fact that this law is reduced in scope mean that its ambiguous provisions will be dictated by circulars and implementing regulations and are unlikely to change facts on the ground in the near term.

Apart from the fact that Beijing still protects the interests of domestic businesses by maintaining the Catalogue of Foreign-Invested Industries and the Negative List, article 20 allows the State to take control of foreign investment in the interest of the public. Yet what defines public interest is not clear.

Article 22 states that "Administrative organs and their employees must not force the transfer of technology through the use of administrative measures". By protecting the intellectual property rights of foreign investors and foreign-invested enterprises, Chinese authorities encourage technological cooperation based "on the principle of voluntariness and business rules". However, such provisions are unlikely to change anything substantial on the ground as the Chinese government has often claimed that such theft does not occur as a matter of policy, despite rampant evidence to the contrary. While Chinese officials deny companies are required to hand over technology, 
foreign businesses face pressures including requirements in industries such as auto-manufacturing and pharmaceuticals to work through state-owned partners, which requires to them provide technology to companies the ruling Communist Party hopes will become their competitors. This fact is coupled with the focus on "administrative methods" that might mean officials still are free to use other tactics to pressure companies to hand over know-how.

In the same way, article 40 allows China to take "corresponding measures" in response to prohibitive or restrictive investment practices by foreign countries. This raises the concern that China will find grounds to exact retribution on foreign companies in response to investment screens abroad, even if there is no legitimate national security concern.

In addition, articles 6 states that foreign investors and foreign-invested enterprises shall not harm national security or the public interest, without any further elaboration. Article 35 further states that any investment that affects or may affect national security will undergo a security review leading to "final decisions". This vague language echoes article 59 of China's 2015 National Security Law, which originally mandated security reviews for such investments. Together, these provisions essentially give the state and, in turn, the CCP free rein to intervene in a wide range of investment activity, signaling to foreign investors that they are better of avoiding any investment in an area that may be construed as politically sensitive or threatening.

In the same vein, the wording of article 42 is problematic. This article only gives foreign businesses a five-year grace period to reorganize their existing corporate structure, mainly joint ventures or wholly foreign-owned enterprises. By not allowing foreign-invested enterprises to retain their existing corporate structures till the end of their current contract, the short timeframe puts pressure on foreign companies whilst at the same time offering opportunity for Chinese shareholders to unfairly renegotiate.

As per article 31, the provisions of the China's Company Law" and China's Partnership Enterprises Law apply to the organizational forms and institutional frameworks of foreign-invested companies. As a result, it is unlikely that foreign businesses will find acceptable, for example, to set up a Communist party branch within the companies, as required by article 19 of China's Company Law. Indeed, the Company Law mandates a direct CCP presence within companies. Article 19 declares that companies must support the activities of any CCP branches established within the firm, in accordance with the Constitution of the Communist Party of China ('Party Constitution'). It is clear that these CCP branches allow the government to extend its tentacles into every significant business organization in China.

Last but not least, and despite further deregulation and institutional reform, serious concerns also remain on how law's enforcement will be handled by local governments. China has often embraced protectionist policies 
at the local level. If the open-up policy involves sectors that have long been dominated by local government-owned enterprises, it means these government-run companies will now face foreign competition. Given that their performance is tied to local governments' fiscal [health], it remains to be seen if local authorities will fully execute the central government's policies.

In sum, it is doubtful that the Investment Law will lead to a level domestic playing field for overseas firms and investors. Irrespective of Chinese government's written undertakings, this State has a good track record of changing low-level regulations to protect domestic industries. The law brings more clarity and enshrines equal treatment in law but doesn't offer complete protection against political influence. Like all Chinese legislations and regulations, this law will continue to provide the $\mathrm{CCP}$ with a great deal of room to intervene, albeit not explicitly.

\section{SECTION III: Features and Issues of the U.S. Multi-faceted Strategy}

A few months after taking office, Trump announced, in his National Security Strategy 2017, that: "We will work with our partners to contest China's unfair trade and economic practices and restrict its acquisition of sensitive technologies".

Taking this line of thought further, the U.S. President claimed in his State of the Union Address 2019 the following:

"As we work to defend our people's safety, we must also ensure our economic resurgence continues at a rapid pace.[...] To build on our incredible economic success, one priority is paramount -- reversing decades of calamitous trade policies. We are now making it clear to China that after years of targeting our industries, and stealing our intellectual property, the theft of American jobs and wealth has come to an end.

In response to President's allegations, USTR Robert Lighthizer underscored that:

"In his State of the Union address, President Trump outlined a visionary trade agenda that resonates across party lines and will accelerate America's manufacturing resurgence, expand export opportunities for our farmers, ranchers and small businesses, and promote America's leadership in today's digital economy. The President is confronting China's unfair trade practices, working to open new trade negotiations with countries around the world, and replacing NAFTA with an innovative, landmark agreement for the 21 st century - the United States-Mexico-Canada Agreement (USMCA). This new agreement is a model for all future trade deals".

These statements describe the current U.S. strategy against China's non-market economic system and state-led, mercantilist trade regime, accused of incrementally distorting international trade to the detriment of the United States and other WTO members. To encourage China to fundamentally change 
its approach to the economy and trade, the United States attempts to consolidate a multifaceted strategy combining both bilateral and international mechanisms. Over the past year, the United States has also increased unilateral corrective actions to limit adverse effects of China's harmful policies and practices.

These mechanisms need to be revised as they only permitted modest results to date.

\section{1) Bilateral Dialogue}

Bilateral dialogue is, for a long time, the main channel used between the parties in response to China's challenges. Since China's accession to the WTO, both parties have repeatedly pursued formal, high-level dialogues through various entities, including previous dialogues like the U.S.-China Joint Commission on Commerce and Trade (JCCT), the U.S.-China Strategic Economic Dialogue (SED) and the U.S.-China Strategic and Economic Dialogue (S\&ED) and a new dialogue known as the U.S.-China Comprehensive Economic Dialogue (CED), which was launched under Trump's administration in April 2017.

Through many years of intensive high-level dialogues, the United States indeed urged China to pursue market-based policies and practices and become a more responsible member of the WTO. But, unfortunately, these efforts largely failed because the Chinese government and the Chinese Communist Party were not sufficiently committed to adopting a true market economy or taking on a more responsible role at the WTO. While the United States has put all its resources and uses all its influence, the result is still an isolated, incremental progress. Considering that these dialogues are largely ineffective, President Trump directed USTR to initiate, in August 2017, an investigation under Section 301 of the Trade Act of 1974 with the goal to address and limit the adverse effects of certain state-led, mercantilist and nonmarket policies and practices of the Chinese government. This investigation aimed only to analyzing policies and practices related to technology transfer, intellectual property and innovation.

As a result, USTR issued, in March 2018, a first report analyzing how China has pursued unreasonable and discriminatory acts, policies and practices that harm U.S. intellectual property rights, innovation and technology development, whilst urging China's officials to initiate structural reforms. The Section 301 investigation and remedies prompted numerous high-level discussions between the United States and China. A second report, issued in November 2018, found that China did not take any of the actions called for by the United States, nor did it commit that it would take any of those actions in the future. These two reports were the grounds for increasing tariffs. 
One more demonstration of the weakness of bilateral dialogue was the exclusion of the U.S. administration and businesses during the course of enacting the new Foreign Investment Law. That reflects, if such were necessary, the unwillingness of China to make deep and structural changes. The Trump's administration has missed an opportunity to address this specific legislation in bilateral trade talks. While the United States could not fundamentally alter the course of China's political system, it would have to press for definitive structural reforms by pointing to this legislation as a key metric for whether China is making good on its commitments to treat U.S. businesses and investors fairly, irrespective of broader trends in the two countries' relations. Beyond this, Trump's administration would have to secure enforcement mechanisms that prevent U.S. investors and companies from being illegitimately drawn into bilateral disputes by having their activity stifled on the vague basis of "national security" or "corresponding measures", among others. Such a possibility is an unacceptable risk if China seeks to ensure a stable, predictable investment regime that adheres to the rule of law and treats foreign investors fairly.

In the above-mentioned context, the awareness of the need for cooperation and damages caused by the trade war to both economies and global trade will probably lead to an agreement in a near future that could reshuffle the cards by creating new opportunities and more trusting environment.

Nonetheless, such an agreement will probably not fulfil the hopes that some place in it. The bilateral approach chosen by the U.S. will not be enough to ensure a sustainable remedy to China's challenges and effective global trade governance. Political one-upmanship and media campaign led by the Trump's administration have only resulted in limited China's concessions. A thorough analysis of the U.S. position during the negotiations has shown that the U.S. authorities pursued five broader purposes as key conditions for ending the trade war: 1) the reduction of the trade deficit with China, 2) a sweeping overhaul of China's economic and legal model, 3 ) the stability of the exchange rate between the dollar and the Chinese yuan, 4) China's compliance with WTO disciplines and its effective participation in the reform of WTO's architecture and rules, and 5) a unilateral verification and enforcement mechanism, including the maintenance of tariffs imposed since July 2018 by the United States on Chinese goods to ensure that Beijing complies with the trade agreement.

Despite important commitments, this agreement will not be able to address several core, thorny issues between the U.S. and China, nor will it change the way China's economy operates. The two sides should reach an agreement on some trade issues, including China's expansion of imports of over a trillion dollars of U.S. goods in the next six years to reduce its trade 
surplus with the U.S. A consensus is also tending to emerge on key issues, including enhancement of protection of intellectual property rights, commitments by Chinese government not to force technology transfer and widening access to China's markets. Beijing has agreed to open its financial and agricultural markets but made its own demands in return, such as allowing Chinese companies to participate in U.S. insurance and other markets. It also seeks looser restrictions on exports to China of sensitive technologies such as artificial intelligence.

U.S. negotiators have, however, tempered demands and left other structural issues for future negotiations, including state-owned enterprises and market-distorting subsidies. These thorny issues will not probably give rise to very detailed or specific engagements because they are intertwined with the Chinese government's industrial policy. The role of state firms may even benefit the U.S. in another part of the trade deal: the purchasing of U.S. goods is likely to reinforce the role of the state sector because the purchasing is all being done through state enterprises. While the two sides reportedly are also near an agreement in which China pledges to have its local governments follow WTO rules on corporate subsidies, Chinese negotiators have acknowledged that the scope of China's local government subsidy programs is largely unknown, making it all that more difficult to include specific commitments in this field (REUTERS, April 16, 2019). No cure has, to date, been found concerning the use by the Chinese government of its judicial system and legislations enforcement with the goal of disciplining the domestic market and achieving industrial policy objectives. Worse still for the U.S., China succeeded in imposing a bilateral monitoring and enforcement framework in which each country would have their own enforcement officers working in their partner's region, and the immediate removal of tariffs imposed since the beginning of the trade war on various products and commodities. This solution guarantees that China will not be held hostage by the U.S. administration that could liberally wield tariffs for any perceived infraction, and undermine their sovereignty as equal partners (BROWN, 2019).

The challenges of a future trade deal reflect in fact those of a bilateral approach, which has to overcome economic, legal and political obstacles.

On the legal front, while a trade deal between the U.S. and China wrapped up with some optimism, such agreement does not resolve the most complex issues between them: intellectual property, technology transfer and market access, along with Beijing's high-tech industrial aspirations.

The U.S. accuses China of stealing intellectual property from American firms, forcing them to transfer technology to China. To address U.S. concerns, Beijing has set up specialized intellectual property courts in various cities and recently passes a foreign investment law which makes it harder for 
Chinese officials to ask foreign firms to transfer their technology to Chinese ones. But American lawmakers point to how China's judiciary is under the control of the Communist Party, and legal decisions go the way this Party wants them to go, in particular when a state-owned enterprise is involved. The enforcement of IPRs will certainly continue to be a major challenge for China.

With regard to market access, China's economic success has been built on the back of a centrally planned, targeted approach, designed for its stateowned companies. That is the opposite of how U.S. companies function. China has promised to open up more sectors of its economy to foreign competition, but that will be meaningless unless it allows its own companies to operate independently.

On the economic front, the Trump's administration should consider that it's not the 80 s anymore. Today, the U.S. needs China more than vice versa. The U.S.-China relationship is already being challenged by other players. Fifteen years ago, China was dramatically underdeveloped, and it wanted access to Western technology and manufacturing techniques. Chinese industry and services can compete today on the world market, and what China doesn't have it can easily obtain from vendors outside the U.S. While the American market looked enticing a few decades ago, it is relatively mature, and today other western trading partners constitute strategic substitute, and the newer emerging market countries have become much more interesting to Beijing (McBRIDE and CHTZKY, 2019).

On the political front, China's trading partners should bear in mind that key change of economic rationale will involve radical political changes in China. State-sponsored capitalism has been essential to China's growth and economic control. The SOEs function as primary conduits to deliver statedriven economic policies and stimulus. As a large employer, SOEs are thus perceived as a cornerstone of social harmony and control over the Chinese society. If the Chinese government withdraws its stranglehold on the economy, the Communist Party loses, as a result, its influence over the Chinese society through the loss of millions of jobs in the State-owned enterprises (FIFIELD and LYNCH, 2019). Ensuring the sustainability of the state regime would have often led to the adoption of a "bottom line thinking" as it retains strong control to the detriment of economic efficiency, and directly affects the legitimacy of the Communist Party's regime which make China unable to fulfill the commitments it made when it joined the WTO in 2001 (ZHOU, 2019). In such circumstances, it is difficult to see how the future arrangement could go, in this field, beyond providing more disclosure to the WTO on subsidies. For the US and other global players, internal pressure may ultimately be the best impetus for change in China. For some years now, smallto medium-sized Chinese companies loudly complain that they get squeezed out by SOEs, who receive preference in borrowing and on other benefits. 
Above all, the agreement currently being finalized will not attenuate the rivalry between the two countries. Beijing's ambitions still strike at the heart of the existential problem between the two sides. China's industrial roadmap also called "Made in China 2025" may be the biggest stumbling block between the two countries. It has exasperated the U.S., which sees the push as a direct challenge to American supremacy in key sectors such as aerospace, semiconductors and 5G (McBRIDE and CHTZKY, 2019).

In sum, the dialogue between the parties within various institutional frameworks has shown more distrust and evident bad faith between the parties than the objective to seek closer cooperation and narrow the views. The implementation of the bilateral trade agreement will largely depend on the stability of political relations, and the willingness of two countries' leadership. The permanent risk of circumventing of its commitments by each party thus remains high. Decision-makers seem often keener to focus first and foremost on domestic political considerations or nationalist feelings, with the risk to empty the agreement of any content. The trade deal, through its enforcement offices, will not be able to prevent the U.S. from imposing unilateral sanctions against China, nor will it be able to minimise strategic competition between the two States.

The result is that the sword of Damocles is still placed over both sides and global economy. That calls for a long-term multilateral binding solution based on a depoliticization of trade issues and ensuring more legal certainty and predictability for the international trading community.

\section{2) Unilateral Measures}

Together with tariff increases described above, the United States brings indictments against individuals engaging in cyber and physical theft of trade secrets for or on behalf of China. Another remedial action consists of imposing investment restrictions. The U.S. administration hence instructed the Secretary of the Treasury to address concerns about investment in the United States directed or facilitated by China in industries or technologies deemed important to the United States. The United States began implementing the Foreign Investment Risk Review Modernization Act enacted in August 2018 (FIRRMA) to protect critical American technology and intellectual property from potentially harmful foreign acquisitions. It also strengthens the existing mechanism - administered by the Committee on Foreign Investment in the United States (CFIUS) - for reviewing foreign investment in the United States for national security purposes and establishes a process for identifying emerging and foundational technologies that should be added to existing U.S. export controls. The Administration is now implementing this legislation with a view toward addressing the concerns regarding state-directed investment in critical technologies identified in the Section 301 investigation. 
Separately, the United States has actively pursued WTO dispute settlement cases involving China. To date, the United States has brought 23 WTO cases against China and has routinely prevailed in these disputes. The U.S. has, for example, recently initiated dispute settlement at the WTO challenging China's discriminatory technology licensing regulations.

Challenging China before the WTO dispute settlement body remains a critical issue for the United States. In some cases, this State manifestly violates WTO rules. In such cases, China is sufficiently respectful of WTO decisions, and most of time it brings its policies in line with WTO findings (MERCURIO and TYAGI, 2012). At the same time, this assessment should be moderated by the persistent difficulty with pressing and winning cases against China given the unwillingness of businesses to stand up and be public with their complaints for fear of China's discretion in granting favors and market access (LEVY, 2019).

The major difficulty is not with the enforcement mechanism, but rather with incomplete and outdated WTO agreements. Obstacles to address subsidies and State-owned enterprises in the current WTO framework are a glaring expression of the gap between U.S. aspirations and outcomes. Many of the most harmful policies and practices being pursued by China in these areas are not even directly disciplined by WTO rules. Beyond the texts and commitments themselves, China runs, in fact, counter to the very rationale of the WTO system. The WTO's dispute settlement mechanism is designed to address good faith disputes in which one member believes that another member has adopted a measure or taken an action that breaches a WTO obligation. This mechanism is not designed to address a trade regime that broadly conflicts with the spirit and fundamental underpinnings of the multilateral trading system. No amount of WTO dispute settlement by other WTO members would be sufficient to remedy this systemic problem (LEVY, 2019).

Two examples suffice to illustrate that any suggestion that the United States or other WTO members could address China's challenges solely by relying on the WTO dispute settlement mechanism is naïve in theory, and likely to prove downright harmful in practice. First, the United States continues to defend U.S. trade remedy laws from attack by China in the WTO. These laws are critical to ensure that the costs associated with China's nonmarket policies and practices are not borne by U.S. companies and workers. To be more effective, the United States is working closely with the European Union (EU) to oppose China's unfounded WTO challenge against the use of non-market economy methodologies in antidumping proceedings. Second, it is striking that China has recently indicated its support for proposals that would give more power to the WTO's Appellate Body. In other words, China has apparently concluded that the Appellate Body is more likely to protect 
China's non-market economic system than to pressure China to change that system.

\section{3) International Dialogue}

In international fora, the United States works with trading partners that share its vision to take effective action to address market-distorting practices in China. Currently, the United States is working with the EU and Japan as part of a new high-level trilateral partnership to address directly the systemic distortions caused by China's non-market economic system. This partnership coordinates joint actions and examines potential rules for disciplining a stateled, mercantilist trade regime where existing rules are ineffective. As this work progresses, the three partners intend to reach out to other like-minded WTO members.

It is worth mentioning that, in comparison with the U.S. position, the EU is sharing the same concerns about Chinese market distortions and is expressing deep skepticism about China's commitment to opening its market further and assuming greater responsibility in global trade governance, besides concern that it seeks to divide the world's largest trading bloc with its economic influence in Eastern Europe.

Nonetheless, there are strong differences both in the acceptance of China's role as an economic and political superpower, and in remedies limiting trade imbalance. European officials suggest that Trump, who has also targeted Europe with tariffs, has created a window of opportunity to show that EUChina relations can be a bulwark for global trade. They urge China, the United States and other countries to avoid trade wars and reform the World Trade Organization, equipping it to combat forced technology transfers and government subsidies, complaints underpinning Trump's tariffs. While the United States claims China's unfair policies are too urgent and too big for the trade body to handle, reforming the rules-based international order as regulated by the WTO is the only way for the EU to tackle China's abuses and stand up against Trump's “America First" policies.

Another divergence is the EU's goal to conclude a bilateral investment treaty with China. To that end, Beijing and Brussels have recently submitted market access offers for the first time as part of investment treaty talks, hence opening a "new phase" in the negotiations that both sides viewed as "a top priority" (SHEPHERD, 2018).

Few weeks after his inauguration as U.S. President, Donald Trump withdrew the United States from the Trans-Pacific Partnership (TPP), a "mega" regional free trade agreement that would have established the world's largest free trade zone. The U.S. should promptly rejoin the TPP. Its withdrawal from the TPP benefits China for several reasons. The return of the U.S. in this forum may provide another leverage effect to discipline China's 
policies and practices. China has achieved on the ground a major strategic advantage in Asia through its own rival free trade agreement and now will be able to write the rules for trade in Asia and possibly beyond. The TPP would also have resulted in significant economic gains to the United States as supported by a large body of economic studies (CHOW, SHELDON and McGUIRE, 2018).

The WTO is the cornerstone of the multilateral trading system but its rules need to be modernized and some gaps must be filled to ensure a level playing field and eliminate unfair practices deployed by China. On the ground, recent reform proposals presented by some WTO members seem only marginally focused on the China's problem. While these proposals potentially could address some behaviors that make China an irresponsible member of the WTO, they do not directly address the serious threat that China and its stateled, mercantilist trade regime poses for individual WTO members and the multilateral trading system.

Meanwhile, several reasons suggest that the adoption of multilateral rules within WTO fora with the goal to oversee China's current approach to the economy and trade is so far "unrealistic".

Firstly, new WTO rules disciplining China would require agreement among all WTO members, including China. However, China has shown no willingness to make fundamental changes to its economic system or trade regime, and it is therefore highly unlikely that China would agree to new disciplines targeted at its trade policies and practices.

Secondly, China has a long record of not pursuing ambitious outcomes at the WTO. Past agreements, even relatively narrow ones, have been difficult to achieve, and when an agreement is achieved, it is significantly less ambitious because of China's participation. One relatively recent example is the negotiation to expand the Information Technology Agreement concluded in December 2015, but the product coverage was significantly reduced from what had been under consideration before China's involvement. Other negotiations do not even lead to an agreement. Rather, they simply reach an impasse once China intervenes. The attempt to negotiate an Environmental Goods Agreement (EGA) is one example. This negotiation began in July 2014 with 14 WTO members, accounting for more than 90 percent of global trade in environmental goods.

Finally, as should be clear, China's continued insistence that it is a developing country significantly hinders the chances of meaningful progress in any type of WTO negotiation. In the unlikely event that members were able to reach a trade liberalizing agreement at the WTO, it likely would not significantly constrain China, as China would insist on availing itself of the "special and differential" treatment incorporated for the benefit of true developing country members. Moreover, because China refuses to recognize 
differentiation between varying levels of development among developing countries, true developing country members likely would not benefit from the most helpful treatment, as China would reject provisions crafted to make "special and differential" treatment available in ways targeted to address the difficulties that different types of developing country members confront when attempting to implement new obligations.

\section{SECTION IV- Recommendations for Promoting a Constructive Partnership}

Previous developments have shown the urgent need for strengthening economic relationship between the U.S. and China, but also the absence of certainty and sustainability of the solutions proposed by the future trade deal. Given the magnitude of their trade and investment links, and their impact over global economy, the challenge is to promote the establishment of what we may qualify of a "constructive partnership", the only way to regulate the rivalry or antagonism between two superpowers and to ensure a more effective global trade governance. China is, simultaneously, in different policy areas, a cooperation partner with whom the U.S. has closely aligned objectives, a negotiating partner with whom the U.S. needs to find a balance of interests, an economic competitor in the pursuit of technological leadership, and a systemic rival promoting alternative models of governance. This requires a flexible and pragmatic whole-of-U.S. approach enabling a principled defence of interests and values.

With this in mind, the success of the multifaceted approach requires a shift in the spirit and objectives displayed by both protagonists. The United States has to assimilate that the balance of challenges and opportunities presented by China has shifted. In the last decade, China's economic power and political influence have grown with unprecedented scale and speed, reflecting its legitimate ambitions to become a leading global power. The U.S. should acknowledge China's political and economic foundations, and grant concessions in sectors considered to be of higher priority by the Chinese government.

In turn, China can no longer be regarded as a developing country. It is a key global actor and leading technological power. Its increasing presence in the world, including in the United States, should be accompanied by greater responsibilities for upholding the rules-based international order, as well as greater reciprocity, non-discrimination, and openness of its system. China's publicly stated reform ambitions should translate into policies or actions commensurate with its role and responsibility. The first step forward would be the China's acceptance to give up the "special and differential treatment" it enjoys as developing country at the WTO. As a reminder, a "developing country" status enables China, among others, to provide subsidies in 
agriculture and set higher barriers to market entry than more developed economies. While Brazil has agreed to forgo the status in exchange for the U.S. support in joining the Organization for Economic Co-operation and Development (OECD), the recent coalition constituted with India, South Africa and Venezuela to make a common front against proposals reforming the "special and differential treatment" is becoming unjustifiable given the importance and particularities of China's economy compared with other developing countries.

Based on these observations, one should draw several consequences and perspectives.

Unilateral sanctions and measures are not the appropriate solutions against China. Such instruments worsen protectionist climate and first punish China's competitors and slow global growth. They also fail to provide sufficient deterrence and reverse China's positions on key issues. In that regard, a more efficient use of WTO litigations requires, as a prerequisite, the reform of WTO agreements so as to integrate China's trade policies and practices, particularly concerning subsidies, forced technology transfer and SOEs.

While all bilateral trade mechanisms between the two countries have all been cut off since Trump took office, the recent set-up of a binding bilateral verification and enforcement mechanism may constitute a new opportunity to ensure a more institutionalized and regular dialogue between both parties. To work more efficiently than in the past this, however, requires a win-win partnership and the acknowledge of Chinese characteristics. Above all, the bilateral approach will not lead to exert enough pressure over China to modernize, in a substantive manner, its economic and legal framework. But despite its deficiencies, the bilateral approach, in particular the enforcement offices set up by the trade deal, should be promoted since it can at least uphold a smooth and regular dialogue, and provide a standing and regular platform for settling future dispute between the U.S. and China. In this respect, trump administration's refusal to make any final trade deal contingent on the reopening of discussions on a bilateral investment treaty (BIT) with China reflects an outdated and inadequate distrust. Such a binding instrument could go further than trade deal commitments or WTO disciplines in this area by establishing more accurate terms and conditions for foreign investments in China by U.S. nationals and businesses, combined with dispute settlement provisions enabling a neutral legal recourse mechanism for both individual investors and the U.S. government. Despite the administration's skepticism of such mechanism, this may serve as a viable course to hold China accountable to its commitments. It is difficult to believe that the enforcement offices set up by the future trade deal may constitute an adequate substitute for a binding arbitral proceeding. 
From a Multilateral perspective, the U.S. and China should continue to cooperate towards an effective multilateralism. The U.S., like other major partners, including the EU, is committed with China to uphold the rules-based international trade order. Accordingly, global players should strengthen cooperation with China to meet common responsibilities across all three main functions of the WTO: trade negotiations, dispute settlement, and trade policy review. China has regularly expressed its commitment towards a fairer and more equitable global governance model by adopting market economy reforms and taking on a more responsible role at the WTO. At the same time, China's engagement in favor of multilateralism is sometimes selective and based on a different understanding of the rules-based international order. China has often repeated its legitimate request for reforming global governance under the aegis of the WTO. But when comes the time to modernize WTO agreements to a more adapting world and make more flexible negotiations and decision-making processes or to give more participation and support to "real" emerging economies, it has not always been willing to accept new rules reflecting the responsibility and accountability that come with its increased role. Selectively upholding some norms at the expense of others thus weakens the sustainability of the rules-based international order.

In this context, and to give consistency to their current informal efforts, the U.S. and other major players of international trade should promptly institutionalize their dialogue and gradually integrate China to their talks through the creation of a Joint Working Group on World Trade Organization reform. At the same time, if the implementation of such a collaborative approach may involve a greater or lesser number of States, the results should only be conceived within the framework of the WTO. Even progress and concessions made within regional or international fora, such as OECD, APEC and G20, will need to be transposed into WTO rules in order to support the credibility and coherence of the global trade order. In other words, not only the response to China's challenges must be collective when it comes to leading negotiations, implementing any agreement, or imposing sanctions against China, but the response should also be ultimately multilateral.

The fact that the EU and the U.S. are currently engaged in separate bilateral dialogue with China, respectively through a joint working group established at the occasion of the 2018 EU-China Summit, and the implementation of the trade deal, illustrates the inconsistency of the current bilateral-based dialogue aiming to tackle global key and common challenges. There is little prospect that one of these instruments produces major impact on the ground on China's most harmful trade practices. The lessons of past experience teach us that adopting a unified position through a strategic alliance between China's major trading partners is the only way to put a real pressure over China, and the cornerstone of any modernization of its economic and 
trade regime. A top priority in this regard, and an indicator of China's commitment, would be to start negotiations on stronger disciplines on industrial subsidies. Making progress towards changing China's status of "developing country" within the WTO will also be of critical importance.

\section{SECTION V - Conclusion}

The above discussion suggests, at least, three comments.

First, China's trade regime generates many WTO compliance concerns. When compared to the policies of other WTO members, China is distorting global markets by prioritizing political considerations over economic incentives. China's industrial and agricultural policies remain fundamentally different. In several significant ways, China's policies go well beyond traditional approaches to guiding and supporting domestic industries, services and agriculture. In addition, China's regulatory regime in many respects remains opaque, which enables the government to pursue other problematic policies and practices that are difficult to uncover. When combined with China's large size and large share of global trade, the U.S. authorities consider that the benefits that Chinese industry realizes largely come at the expense of China's trading partners and their companies and workers.

Second, the China's position is built on two pillars. On one side, a fundamental issue remains the Chinese government and Communist Party's belief that the political value of maintaining a socialist market economy together with a State-led and mercantilist approach to trade still outweigh the economic costs. The party control is more important than economic growth, even though the results have contributed to China's economic slowdown with resources pouring into State companies, thus rewarding inefficiency and acting as a drag on China's performance. Another factor holding reforms back might be Beijing's belief that its industrial policy is giving it an advantage. Chinese's administration thinks that one of the motivations for the U.S. to be so aggressive in recent months is that the U.S. also thinks China's industrial policy plans are working.

Third, since economic and technological rivalry between two superpowers is inevitable, the challenge is to pave the way for a rules-based coexistence that eases global trade governance. Convincing China to make the needed fundamental changes to its trade regime requires a more constructive diplomacy through a multifaceted, long-term and collective approach. In several cases, WTO members have had to resort to the WTO's dispute settlement mechanism to change problematic Chinese policies and practices. Despite a real success, the use of this tool is sometimes disappointing. China's trade distortions do not often violate WTO agreements, being more related to China's political and legal model not sufficiently liberalized and transparent. 
While the Trump administration's trade policy gives the priority to unilateral trade barriers and the deadlock of the multilateral trading system as regulated by the WTO, it would be more relevant to adopt, among others, the following measures: 1) the conclusion of a bilateral investment treaty with China; 2) the accession to the Trans-Pacific Partnership; and 3) the institutionalization of a like-minded States joint working group on WTO reform with the objective of revitalizing multilateral rules and governance.

\section{References:}

1. BROWM (Randy), U.S.-China Trade Deal Will Be More Substantial Than Expected, Forbes, April 18, 2019.

2. CANUTO (Otavio), China's Growth Rebalance With Downslide, Seeking Alpha, March 3, 2019, (available on: https://seekingalpha.com/article/4246051-chinas-growth-rebalancedownslide).

3. CHOW (Daniel), SHELDON (Ian) and McGUIRE (William), How the United States Withdrawal from the Trans-Pacific Partnership Benefits China, Ohio State Public Law Working Paper No. 451, August 2018, 32 pages.

4. FIFIELD (Anna) and LYNCH (D.), In Pursuing a Trade Deal, the US May Be Asking China to Do the Unthinkable, The Washington Post, February 14, 2019.

5. HEALEY (Deborah) and WANG (Lu), China's proposed Law on Foreign Investment. Will the new Law be Welcoming enough for Investors?, Asian \& The Pacific Policy Society, March 4, 2019, (available on https://www.policyforum.net/chinas-proposed-law-onforeign-investment/).

6. LEVY (Phil), The China Enforcement Puzzle, Forbes, February 28, 2019.

7. LOWE (Austin), China's Foreign Investment Law Fails to Address U.S. Concerns, Lawfare, March 7, 2019, (available on: https://www.lawfareblog.com/chinas-foreign-investment-law-failsaddress-us-concerns).

8. McBRIDE (James) and CHTZKY (Andrew), Is 'Made in China $2025^{\prime}$ a Threat to Global Trade?, Council on Foreign Relations, March 7, 2019 (available on: https://www.cfr.org/backgrounder/made-china2025-threat-global-trade).

9. MERCURIO (Bryan) and TYAGI (Mitali), China's Evolving Role in WTO Dispute Settlement: Acceptance, Consolidation and Activation, European Yearbook of International Economic Law, vol (3), 2012, pp.89-123. 
10. NEE LEE (Yen), The US and China may be nearing a trade deal. That won't stop the global economic slowdown, CNBC, February 25, 2019.

11. QINGJIANG (Kong) and WEIHUAN (Zhou), China's New Law Outlaws Forced Technology Transfer, CGTN, March 17, 2019.

12. REUTERS, Keen for trade deal, US softens demand for China subsidy cuts, April 16, 2019. REUTERS, Top U.S. trade officials head to China next week for new trade talks, March 19, 2019.

13. REUTERS, China says U.S. report on its WTO compliance lacks factual basis, February 5, 2019.

14. SHEPHERD (C.), EU pushes China on trade, saying it could open up if it wanted, Reuters, July 16, 2018.

15. USTR, 2018 Report to Congress on China's WTO Compliance, February 2019.

16. USTR, Section 301 Report into China's Acts, Policies, and Practices Related to Technology Transfer, Intellectual Property, and Innovation, March 27, 2018.

17. USTR, Update Concerning China's Acts, Policies and Practices related to Technology Transfer, Intellectual Property, and Innovation, November 20, 2018.

18. WTO, Trade Policy Review - China, Report By the Secretariat, June 6, 2018, WT/TPR/S/375.

19. WTO, Trade Policy Review, Report by the Government, June 6, 2018, WT/TPR/G/375.

20. ZHOU (Cissy), China risks 'the legitimacy of the Communist Party's regime' without changes, says law professor', March 22, 2019, South China Morning Post. 